\title{
Impact of Liquidity Management on the Profitability of Banks Operate in Palestine
}

\author{
Khaled Zidan \\ Department of Banking and Finance \\ Faculty of Economics and Social Studies \\ An-Najah National University \\ Palestine
}

\begin{abstract}
This study aims to explain the effect of the liquidity management on the profitability of the Palestinian banking sector during the time period 2008-2017. Palestinian banking sector has been chosen for the purpose of this study, which comprised from 14 banks Islamic and commercial. Multiple regression models were used to do the empirical analysis and; develop the econometric model which consisted of one dependent variable and eight independent variables. Return On Assets (ROA) was defined as profitability indicator. The data was collected from the audited annual reports of the sample banks, the Palestinian Monetary Authority (PMA)'s annual reports and Association of Banks in Palestine. The findings and analysis revealed that loans to deposits ratio had the most important significant effect on profitability.
\end{abstract}

Keywords: Liquidity, Profitability, Banking sector, Palestine.

\section{Introduction}

Banks' liquidity management is central to the implementation of monetary policy. By affecting the trade-off between lending and holding liquid assets, central banks affect the supply of loan able funds, and through this channel they affect the real economy. Understanding how banks manage liquidity is, thereby, essential to understanding the implementation of monetary policy. However, macroeconomic models, especially those used for monetary policy analysis, largely abstract how banks manage liquidity (Cetorell et al, 2010). It has to be mentioned that Liquidity Management reduces the bank's risk, risk in not meeting its obligations on time or reducing the profitability of the bank. The aim of this study is to make clear how Liquidity Management impacts the profitability of banks in general, more specifically banks in Palestine. A firm should ensure that it does not suffer from lack-of or excess liquidity to meet its short-term compulsions. A study of liquidity is of major importance to both the internal and the external analysts because of its close relationship with day-to-day operations of a business (Carey, 1998). Dilemma in liquidity management is to achieve desired trade-off between liquidity and profitability (Bordeleau et al, 2010). It cannot be understated how important a solid base of Liquidity Management is for a bank's future operations, securing its future in of itself.

The name of banking business is so risky and sensitive and banks are about risk management because most of banks' money is depositors' money. Banks use these deposits to create credit for their borrowers, and this requires optimum utilization of the available resources, since the bank is expected at any moment to meet the obligations of its clients and depositors who want to withdraw their savings, and so the bank should be ready to meet these demands at any time.

The problem arises when a bank is not be able to meet demand for liquidity, especially those unexpected ones , negatively effects its earning level. Therefore, banks have to work to maximize their profit, and at the same time be able to meet liquidity needs, by holding a sufficient amount of liquidity to achieve a balance between profitability and liquidity, since there is a trade-off between liquidity and profitability. The more resources are tied up in readiness to meet demand for liquidity, the lower the profitability. The main aim of this study was to find out and describe the impact of banking liquidity management on the Palestinian banking sector profitability, considering their need to keep a highest balance between liquidity and profitability.

\section{Related Literature}

\subsection{Previous Studies}

The objective of this review is to examine and explore the main empirical results of related studies which examine the variables particularly that concern of the internal determinants of commercial bank's profitability. A study by Lartey et al. (2013) examines how banks and firms should manage their liquidity at periods when there is a financial crisis. It showed how companies substitute between credit lines and internal liquidity (cash and profits) when facing a severe credit shortage. As a result it indicated that credit lines eased the impact of the financial crisis on corporate spending. 
A study by Alshatti (2015)seeks to investigate the effect of the liquidity management on profitability in the Jordanian commercial banks during the time period (2005-2012). Thirteen banks have been chosen to express on the whole Jordanian commercial banks. The conclusion of this study that there is an effect of the liquidity management on profitability in the Jordanian commercial banks as measured by ROE or ROA, where the effect of the investment ratio and quick ratios on the profitability is positive when measured by ROE, and the effect of capital ratio on profitability is positive as measured by ROA, and the effect of the other independent variables on the two measures of profitability (ROE and ROA) is negative, the researcher believes that this negative effect is due to the increased volume of untapped deposits at the Jordanian commercial banks. Also Aburime (2008) examined liquidity management and commercial banks' profitability in Nigeria. The major aims of the study were to find empirical evidence of the degree to which effective liquidity management affects profitability in commercial banks and how commercial banks can enhance their liquidity and profitability positions. The conclusions of the study: For the success of operations and survival, commercial banks should not compromise efficient and effective liquidity management. They are expected to maintain optimal liquidity level in order to satisfy their financial obligations to customers or depositors and maximize profits for the shareholders. Also, effective liquidity management also requires adequate liquidity level which will help commercial banks to estimate the proportion of depositor's funds that will be demanded at any period and arrange on how to meet the demand .So It can finally be concluded that liquidity is inversely related to profitability. That means as liquidity increases, profitability decreases.

\subsection{Banking Risk Management}

Description of risk: risk refers to the uncertainty that surrounds future events and outcomes. It is the expression of the likelihood and impact of an event with the potential to influence the achievement of an organization's objectives. The phrase "the expression of the likelihood and impact of an event" implies that, as a minimum, some form of quantitative or qualitative analysis is required for making decisions concerning major risks or threats to the achievement of an organization's objectives, for each risk (Berg et al, 2010).That was the concept of risk itself, but when it comes to risk management the concept is different, one well accepted description of risk management is the following: risk management is a systematic approach to setting the best course of action under uncertainty by identifying, assessing, understanding, acting on and communicating risk issues. In order to apply risk management effectively, it is vital that a risk management culture be developed. The risk management culture supports the overall vision, mission and objectives of an organization. Limits and boundaries are established and communicated concerning what are acceptable risk practices. (Berg, 2010).

\subsection{Overview of the Palestinian Banking Sector}

The banking sector has great impact on the Palestinian economy, as it is the main funding channel for the private and public sector and the main source of credit in the local market due to the capital market weakness and limitation, and the lack of the ability to provide adequate sources of financing to investors (Ja'afari, 2003)). The Palestinian Monetary Authority (PMA) act as the central bank of Palestine, in which established by presidential decree in 1994 following the Oslo Agreement. The Palestinian banking sector consists of domestic and foreign banks. Fourteen banks operate in Palestine, seven of them are domestic (three of them are Islamic) and the rest are foreign with a total of 343 branches and offices The banking sector has total assets reaching USD 16.125 billion, deposits of US\$ 12 billion and credit facilities of US\$8 billion at the end of year 2018 (PMA, 2018).

\subsection{Hypothesis of Study}

In the light of study objectives, the present study sought to test the following hypotheses; Hypotheses can be classified into one major hypothesis subdivided into eight sub-hypotheses:

Major premise: There is no significant relationship between liquidity management and banks' profitability. A subhypothesis emerges from the major one.

HO 1: There is no significant relationship between Loan Deposit Ratio and bank's profitability.

HO 2: There is no significant relationship between Deposit Asset Ratio and bank's profitability.

H0 3: There is no significant relationship between Liquid Asset Ratio and bank's profitability.

HO 4: There is no significant relationship between Net Loans to Total Assets and bank's profitability.

HO 5: There is no significant relationship between Loan Loss Provisions to gross loans and bank's profitability.

H0 6: There is no significant relationship between Loans less Customer Deposits to Total Assets and bank's profitability.

H0 7: There is no significant relationship between Cost to Income Ratio and bank's profitability.

HO 8: There is no significant relationship between Capital Adequacy Ratio and bank's profitability. 


\section{Methodology and Research Design}

\subsection{Sample of the Study}

Palestinian banking sector has been chosen for the purpose of this study; however, the Safa Islamic bank has been excluded from this study. In other words, fourteen banks comprised the study sample during the period 2008-2018. (Seetable 1).

\subsection{Methods of Collecting Data}

The data was collected from annual financial statements, Association of banks in Palestine and from the PMA (Palestinian Monetary Authority). The data was collected from 2008-2017. The study looked for liquidity management disclosure. In Palestine, banks have to prepare annual reports and submit them for the PMA; it makes it easy to collect data about each bank and to get all of the annual reports needed for the study. The Quantitative Data were eight financial ratios measuring the eight independent variables of the study. These ratios are mainly related to the Liquidity Management in Banks, each of the ratios and there explanation will be part of the applied regression model.

\subsection{Data Analyzing Instruments}

The researcher used multiple regressions to analyze the data collected from banks. This means there was one dependent variable and eight independent variables in the model, the regression outputs were obtained by using SPSS and Statistical package for social science.

Table 1: Selected data for the sample banks for the year 2017 in USD millions

\begin{tabular}{|l|l|l|l|l|l|}
\hline Bank & Total Assets & Total Equity & Total Revenue & Customer Deposits & Net loans \\
\hline Bank Of Palestine & $1,286,036,545$ & $449,961,687$ & $220,934,607$ & $3,768,631,790$ & $2,518,590,540$ \\
\hline Arab Islamic Bank & $1,041,103,696$ & $106,995,915$ & $33,905,595$ & $790,906,601$ & $560,923,314$ \\
\hline Palestine Islamic Bank & $1,010,369,417$ & $109,625,653$ & 51.483 .551 & $809,630,033$ & $619,378,328$ \\
\hline Palestine Investment Bank & 443.291 .111 & 90.899 .358 & 19.253 .947 & 297.663 .960 & 210.578 .198 \\
\hline Al Quds Bank & $1,075,629,534$ & $102,730,674$ & $53,678,398$ & $855,348,926$ & $658,517,963$ \\
\hline The National Bank & $1,097,399,362$ & $97,567,177$ & $39,655,177$ & $808,784,822$ & $653,847,526$ \\
\hline Arab Bank & $3,547,941,320$ & $296,020,440$ & $163,140,161$ & $3,022,899,717$ & $1,784,676,441$ \\
\hline Cairo Amman Bank & 971.247 .128 & 103.698 .942$. & 39.956 .911 & 718.627 .032 & 484.585 .223 \\
\hline Bank Of Jordan & 624.428 .031 & 93.459 .150 & 26.962 .628 & 515.293 .186 & 278.444 .475 \\
\hline Housing Bank & 645.348 .587 & 99.190 .300 & 26.756 .075 & 521.282 .010 & 208.358 .488 \\
\hline Egyptian Arab Land Bank & 170.651 .353 & 44.890 .975 & 6.103 .100 & 102.253 .911 & 105.116 .988 \\
\hline Jordan Ahli Bank & 411.958 .896 & 83.898 .798 & 18.626 .159 & 299.040 .866 & 198.784 .700 \\
\hline Commercial Bank of Jordan & 243.997 .773 & 59.692 .117 & 8.865 .454 & 135.384 .701 & 105.166 .913 \\
\hline Jordan Kuwait Bank & 139.801 .616 & 50.935 .221 & 2.834 .808 & 67.257 .401 & 21.496 .172 \\
\hline
\end{tabular}

\subsection{Applied Regression Model}

The researcher to get to the dimensions of the problem built two study models, to clear the relationship between the independent variables of liquidity management which is (Loan Deposit Ratio , Deposit Asset Ratio , Liquid Asset Ratio , Net Loans To Total Assets, Loan Loss Provision To Gross Loans, Loans Less Customer Deposits To Total Assets , Cost To Income Ratio , Capital Adequacy Ratio ) on the first side, and on the other side the dependent variables , Return on Assets (ROA)as profitability indicator.

Table 2.Summary of the independent variables employed in the study

\begin{tabular}{|l|l|l|}
\hline Variable & Measurement & Description \\
\hline Loan To Deposit Ratio & Loan and Advances / Total Deposit & LTD \\
\hline Deposit Asset Ratio & Total Deposit / Total Assets & DTA \\
\hline Liquid Asset Ratio & Liquid Assets / Total Assets & LAT \\
\hline Loans to Total Assets Ratio & & LTA \\
\hline Loan Loss Provisions to Gross Loans & & LLPGL \\
\hline Loans less customer deposits to total assets & & \\
& & LCDTA \\
\hline Cost to income ratio & Non- interest expense to total revenue & CIR \\
\hline Capital Adequacy Ratio & total equity capital / total Asset & CAR \\
\hline
\end{tabular}


Based on that and in the light of the elements and the dimensions of the problem the researcher employed multiple regression model (presented below) to highlight the relationship between the independent variables on the one hand and the dependent variables (Return on Assets (ROA)on the other hand. The following mathematical equation illustrates the model: Thus the regression equations become:

\section{Model}

$\mathrm{ROA}=\mathrm{a}+\mathrm{B} 1(\mathrm{LTD})+\mathrm{B} 2(\mathrm{DTA})+\mathrm{B} 3(\mathrm{LAT})+\mathrm{B} 4(\mathrm{LTA})+\mathrm{B} 5(\mathrm{LLPGL})+\mathrm{B} 6(\mathrm{LCDTA})+\mathrm{B} 7(\mathrm{CIR})+\mathrm{B} 8(\mathrm{CAR})+\mathrm{e}$

\section{Empirical Findings and Analysis}

\subsection{R Square Analysis}

Adjusted R2 (65.6) avoids the overestimation effect of adding other variables as independent variables to the model. Therefore, adjusted R differing by 5\% $(70.6 \%-65.6 \%=8.7 \%)$. The Durbin-Watson statistic was 1.932 is less than 2, it means that there was no serial correlation between independent variables and ROA.

Table 3. Results of $R$ square analysis

\begin{tabular}{|l|l|l|l|l|l|}
\hline Model & R & R Square & Adjusted R Square & Std. Error of the Estimate & Durbin-Watson \\
\hline 1 & $.840(a)$ & .706 & .656 & .49267 & 1.932 \\
\hline
\end{tabular}

a Predictors: (Constant), LTD,DTA,LAT,LTA,LLPGL,LCDTA,CIR,CAR

b Dependent Variable: ROA

\subsection{The Regression Results}

Table 4. Multiple Linear Regression Matrixes for the model

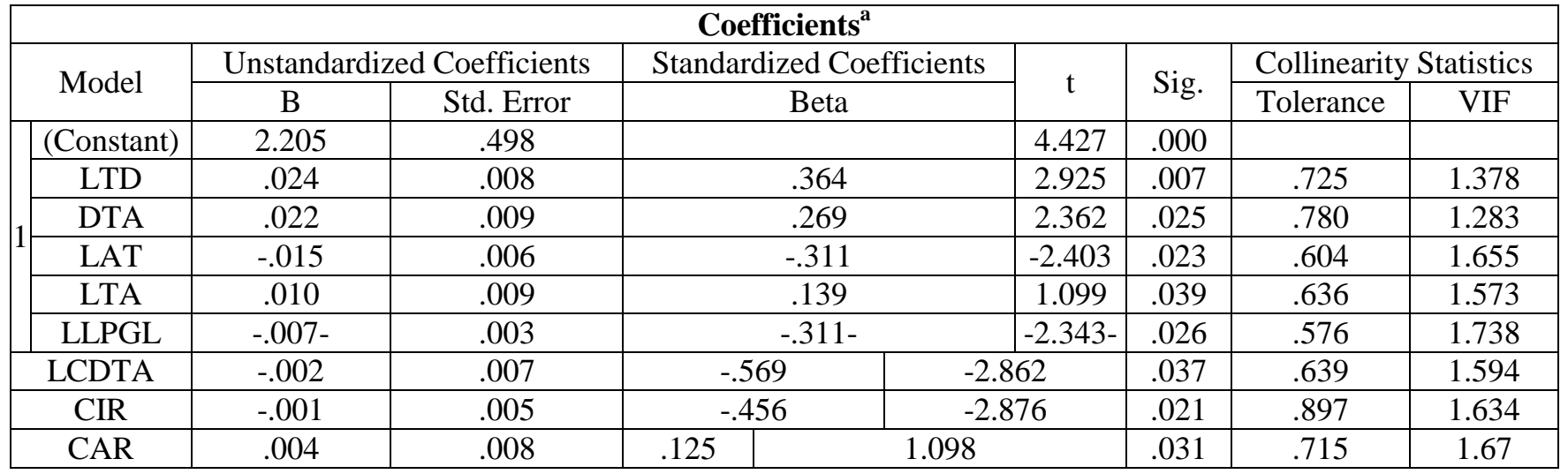

Dependent Variable: ROA

\subsubsection{The Relationship between Loan Deposit Ratio (LTD) and Profitability}

H01: There is no significant relationship between Loan deposit ratio and bank's profitability.

The results presented in table 4 showed that LTD affected ROA positively. LTD $\beta$ coefficient is .024 which means that one unit increase in LTD increases ROA by $2.4 \%$ unit while the rest of variables are held constant. The statistical significance of LTD on ROA is.007 which is less than 0.05. This means that LTD predicts effect on ROA with 99.3\% probability (significant relationship). The research study strongly believes that if the banks concentrate the loan deposit ratio will increase the profitability of the bank. Therefore, the null hypothesis will be rejected and accept the alternative one: H 1: There is significant relationship between Loan deposit ratio and bank's profitability.

\subsubsection{The Relationship between Deposit Asset Ratio (DTA) and Profitability}

H02: There is no significant relationship between Deposit asset ratio and bank's profitability. The results presented in table 4 indicate that DTA was positively related to (ROA), the profitability measure. The $\beta$ coefficient was 0.022 which indicates that the effect of DTA on ROA was weak. This indicates that one unit increases in DTA will increases ROA by $2.2 \%$ units, holding the rest of variables constant. The statistical significance of DTA was 0.025 which was a sign of significance relationship. Therefore, the null hypothesis will be rejected and accept the alternative one: H2: There is significant relationship between Deposit Asset Ratio and bank's profitability.

\subsubsection{The Relationship between Liquid Asset Ratio (LAT) and Profitability}

H O3: There is no significant relationship between Liquid Asset Ratio and bank's profitability. The results showed that LAT affected ROA negatively. LAT $\beta$ coefficient is -.015 which means that one unit increase in LAT decreases ROA by $1.5 \%$ unit while the rest of variables are held constant. 
The statistical significance of LAT on ROA is..023 which is less than 0.05.This means that LAT predicts effect on ROA with $97.7 \%$ probability (significant relationship). It implies that their negative relationship between liquidity and profitability. Therefore, the null hypothesis will be rejected and accept the alternative one: HO 3: There is significant relationship between Liquid asset ratio and bank's profitability.

\subsubsection{The Relationship between Loans to Total Asset (LTA) and Profitability.}

H O4: There is no significant relationship between Net Loans to Total Assets and bank's profitability. The results showed that LTA affected ROA positively. LTA $\beta$ coefficient is .0221 which means that one unit increase in LTA increases ROA by $2.21 \%$ unit while the rest of variables are held constant. The statistical significance of LTA on ROA is 0.039 which is less than 0.05.This means that LTA has significant relationship with ROA. It implies that LAT predicts ROA with $96.1 \%$ probability. Based on that, we can tell that Banks that invest more in loans are better able to increase their profitability than banks that do not. Therefore, the null hypothesis will be rejected and accept the alternative one: H 4: There is significant relationship between Net Loans to Total Assets and bank's profitability.

\subsubsection{The Relationship between Loan Loss Provisions to Gross Loans (LLPGL)and Profitability.}

H O5: There is no significant relationship between Loan loss provisions to gross loans and bank's profitability.

The results presented in table 4 indicated that Loan Loss Provisions to Gross Loans Ratio (LLPGL) is negatively related to (ROA), the profitability measure. The $\beta$ coefficient was -0.015 which means that one unit increase in LLPGL decreases ROA by $1.5 \%$ units while the other variables are held constant. The statistical significance of LLPI on ROA is 0.026 which is less than 0.05 which is a significant relationship. This means that LLPGL predicts effect on ROA with $97.4 \%$ probability. Therefore, the null hypothesis will be rejected and the alternative one will be accepted: H5: There is significant relationship between Loan loss provisions to gross loans and bank's profitability.

\subsubsection{The Relationship between Loans less Customer Deposits Total Assets (LCDTA) and Profitability}

H O6: There is no significant relationship between Loans less customer deposits to total and bank's profitability. The results presented in table 4 indicated that (LCDT) Ratio is negatively related to (ROA), the profitability measure. The $\beta$ coefficient was -0.002 which means that one unit increase in LLPGL decreases ROA by. $2 \%$ units while the other variables are held constant. The statistical significance of LLPI on ROA is 0.036 which is less than 0.05 which is a significant relationship. This means that LLPGL predicts effect on ROA with $96.4 \%$ probability. Therefore, the null hypothesis will be rejected and the alternative one will be accepted: H 6: There is significant relationship between Loans less customer deposits to total and bank's profitability.

\subsubsection{The Relationship between Cost to Income Ratio (CIR) and Profitability}

H0 7: There is no significant relationship between Cost to income ratio and bank's profitability. The results presented in table 4 indicated that (CIR) Ratio is negatively related to (ROA), the profitability measure. The $\beta$ coefficient was 0.001 which means that one unit increase in (CIR) decreases ROA by. $1 \%$ units while the other variables are held constant. The statistical significance of (CIR) on ROA is 0.021 which is less than 0.05 which is a significant relationship. This means that CIR predicts effect on ROA with $97.1 \%$ probability. It is therefore obvious that a lot needs to be done to reduce Operational Expenses such administrative costs in the sector to improve profitability. Therefore, the null hypothesis will be rejected and the alternative one will be accepted: $\mathbf{H}$ 7: There is significant relationship between Cost to income ratio and bank's profitability.

\subsubsection{The Relationship between Capital Adequacy Ratio (CAR) and Profitability.}

H O8: There is no significant relationship between Capital Adequacy Ratio and bank's profitability.

The results presented in table 4 showed that CAR affected ROA positively. CAR $\beta$ coefficient is .004 which means that one unit increase in CAR increases ROA by $.4 \%$ unit while the rest of variables are held constant. The statistical significance of CAR on ROA is.031 which is less than 0.05.This means that CAR predicts effect on ROA with $96.9 \%$ probability (significant relationship).

\section{Conclusions}

Banks, just like all other forms of businesses, face many risks. Liquidity risk is one of the major risks the banking sector faces; it is also the major cause of serious banking problems resulting from poor policies and management of such risks. The aim of this study was to find out the impact of liquidity risk policies adopted by Palestinian banks on their profitability. This study examined the relationship between liquidity management and profitability in Palestinebetween2008- 2017. The quantitative method was used in order to fulfill the main purpose of the study. 
Multiple regression models were used to do the empirical analysis, developing the models; consists of one dependent variable and eight independent variables. The researcher used Return on Assets (ROA) as profitability indicator. In contrast, liquidity management indicators were measured by eight financial ratios available in the financial statements of Palestinian banks. The results obtained from the regression model show that liquidity risk management had a significant impact on profitability with $65.6 \%$ possibility of LTD, DTA, LAT, LTA, LLPGL, LCDTA, CIR and CAR in predicting the variance in ROA. Therefore, one can say that liquidity management strategy determines profitability level to a considerable extent. Despite the positive improvement in ROA as profitability indicators, still banks operate in Palestine (study sample), comparable to industry international standards, were less efficient and had weak performance.

\section{References}

Aburime, T., U. (2008). Determinants of Bank Profitability: Macroeconomic Evidence from Nigeria. Social Science Research Network, Deakin University.

Alshatti, A., S, (2015). The effect of the liquidity management on profitability in the Jordanian commercial banks. International Journal of Business and Management 10, no. 1 (2015): 62.

Berg, A., T. Mirzoev, R. Portillo, and L.F. Zanna,( 2010). The Short-Run Macroeconomics of Aid Ináows: Understanding the Interaction of Fiscal and Reserve Policy,î IMF Working Paper 10/65.

Bordeleau, Étienne, and Christopher Graham. The impact of liquidity on bank profitability. No. 2010, 38. Bank of Canada working paper, 2010.

Carey, M., (1998). Credit Risk in Private Debt Portfolios, Journal of Finance, 53, 1363-1388

Cetorelli, Nicola, and Linda S. Goldberg. "Liquidity management of US global banks: Internal capital markets in the great recession." Journal of International Economics 88, no. 2 (2012): 299-311.

Ja'afari, Mohammed.( 2003) Palestinian Services Sector and Its Role in the Economic Development Process. Ramallah: Mass

Lartey, V., Antwi, S., \&Boadi, E. (2013). The Relationship between Liquidity and Profitability of Listed Banks.

Palestinian Monetary Authority, (2018). Financial stability Report. 